\title{
Community structure of aquatic insects (Ephemeroptera, Plecoptera, and Trichoptera) in Cerrado streams of Paraguay, Paraná, and São Francisco river basins
}

\author{
Renato de Mei Romero ${ }^{1,3}$, Mônica Ceneviva-Bastos ${ }^{2}$, Gustavo Henrique Baviera ${ }^{2}$ \& Lilian Casatti ${ }^{2}$ \\ ${ }^{1}$ Instituto Federal de Alagoas - IFAL, Campus Marechal Deodoro, Rua Lourival Alfredo, 176, \\ CEP 57160-000, Marechal Deodoro, AL, Brasil. www.ifal.edu.br \\ ${ }^{2}$ Departamento de Zoologia e Botânica, Instituto de Biociências, Letras e Ciências Exatas - IBILCE, \\ Universidade Estadual Paulista - UNESP, Rua Cristóvão Colombo, 2265, CEP 15054-000, \\ São José do Rio Preto, SP, Brazil. http://www.ibilce.unesp.br/ \\ ${ }^{3}$ Corresponding author: Renato de Mei Romero,e-mail: romerobio@yahoo.com.br
}

ROMERO, R.M., CENEVIVA-BASTOS, M., BAVIERA, G.H. \& CASATTI, L. Community structure of aquatic insects (Ephemeroptera, Plecoptera, and Trichoptera) in Cerrado streams of Paraguay, Paraná, and São Francisco river basins. Biota Neotrop. 13(1): http://www.biotaneotropica.org.br/v13n1/en/ abstract?article+bn02213012013

\begin{abstract}
We evaluated qualitatively and quantitatively the community structure of aquatic insects (Ephemeroptera, Plecoptera, and Trichoptera) in 19 streams in areas of Cerrado in the Paraguay, Paraná, and São Francisco river basins. The number of genera and taxonomic composition were compared at spatial (at the hydrographic basins level) and conservation levels (more preserved and less preserved areas). The influence of spatial and environmental factors in richness and abundance was also evaluated. The geographical distribution of Grumicha, Coryphorus, and Austrotinodes was expanded. The highest Trichoptera richness was found in the São Francisco river basin $(\mathrm{F}=5,602, \mathrm{p}=0,004)$ and a higher number of Ephemeroptera genera occurred in the relatively less preserved sites $(F=6,835, p=0,009)$. The pattern of genera distribution was different among basins $(R=0,0336, p=0,001)$, but it was similar among relatively less and more preserved areas $(R=-0,039, p=0,737)$. These findings can be explained by the low impact level in these streams and also by the taxonomic resolution used in this study. Latitude and instream diversity were the most important factors to explain the variation in genera richness and abundance ( $p=0.004$ and $p=0.026$, respectively). Hence, the regional differences can be attributed to spatial influences, quantity or quality of habitats and the original distribution of taxa within each basin.
\end{abstract}

Keywords: benthic macroinvertebrates, EPT, biomonitoring, conservation.

ROMERO, R.M., CENEVIVA-BASTOS, M., BAVIERA, G.H. \& CASATTI, L. Estrutura de comunidades de insetos aquáticos (Ephemeroptera, Plecoptera e Trichoptera) em riachos de Cerrado nas bacias dos rios Paraguai, Paraná e São Francisco. Biota Neotrop. 13(1): http://www.biotaneotropica.org.br/v13n1/pt/ abstract?article+bn02213012013

Resumo: Foi avaliada a estrutura quali e quantitativa da comunidade de Ephemeroptera, Plecoptera e Trichoptera (EPT) em 19 riachos em áreas de Cerrado nas bacias dos rios Paraguai (PG), Paraná (PN) e São Francisco (SF). O número de gêneros e a composição taxonômica foram comparados espacialmente (diferentes bacias hidrográficas) e quanto ao grau de conservação (áreas mais e menos preservadas). A influência de fatores espaciais e ambientais na riqueza e na abundancia também foi avaliada. Foi registrada a ampliação da área de ocorrência dos gêneros Grumicha, Coryphorus e Austrotinodes. A riqueza de Trichoptera foi superior na bacia do São Francisco ( $\mathrm{F}=5,602$, $\mathrm{p}=0,004)$ e a riqueza de Ephemeroptera foi maior em áreas relativamente menos preservadas $(\mathrm{F}=6,835$, $\mathrm{p}=0,009)$. O padrão de distribuição dos gêneros diferiu entre as bacias hidrográficas $(\mathrm{R}=0,0336, \mathrm{p}=0,001)$, mas foi igual entre áreas mais e menos preservadas $(R=-0,039, p=0,737)$, o que pode ser explicado em função do baixo grau de impacto existente entre os riachos estudados e/ou pelo grau de resolução taxonômica atingido no presente estudo. A latitude e, secundariamente, a diversidade interna do hábitat aquático foram os fatores que melhor explicaram a variação encontrada no número de gêneros e na abundância $(\mathrm{p}=0,004$ e $\mathrm{p}=0,026$, respectivamente). Assim, as diferenças regionais observadas puderam ser atribuídas às influências espaciais, à quantidade e qualidade de hábitats e à distribuição original dos táxons em cada bacia.

Palavras-chave: macroinvertebrados bentônicos, EPT, biomonitoramento, conservação. 


\section{Introduction}

Benthic macroinvertebrates are important components of freshwater communities; they are widely distributed and occur in several substrate types in freshwater environments (Moretti \& Callisto 2005). The distribution of benthic macroinvertebrates is influenced by the interaction between habits, physico-chemical variables, structural and hydrological characteristics, and by human activities (Resh \& Rosenberg 1984, Merritt \& Cummins 1984). Therefore, changes in water body characteristics, habitat, and environmental resources can strongly influence patterns of spatial and temporal distribution in benthic communities (Buss et al. 2002, 2004, Silveira et al. 2006).

Immature stages of ephemeropterans (mayflies), plecopterans (stoneflies), and trichopterans (caddisflies), which are commonly referred to as EPT, are widely distributed in streams (Hynes 1970, Allan 1995) and have proven to be good surrogates for representing the ecological characteristics of the whole freshwater community (Beauchard et al. 2003). Thus, the evaluation of EPT community structure can bring some fruitful insights on many aspects of stream ecology and also on the understanding of ecological processes at broad scales. In addition, ecological data on these insects provide valuable information for building and improving multimetric indices for biomonitoring (Karr 1991).

Several studies have shown a close relationship between macrobenthic communities and habitat components, as well as the implications of this relationship for biomonitoring (Arunachalam et al. 1991, Cairns \& Pratt 1993, Kerans \& Karr 1994, Galdean et al. 2000, Barbosa et al. 2001, Marques \& Barbosa 2001, Callisto et al. 2004, Hodkinson \& Jackson 2005, Silveira et al. 2006, Ayres-Peres et al. 2006, Milesi et al. 2009). However, studies conducted in pristine and protected areas in Brazil are rare, despite being fundamentally important for biodiversity management in these areas.

In this context, the aim of the present study was to investigate the diversity and composition of aquatic insects (Ephemeroptera, Plecoptera, and Trichoptera) in the Paraná, Paraguay and São Francisco basins, in streams submitted to different conservation status. We described and compared the variations in community structure among these Cerrado basins - which are submitted to different conservation status - and tested how environmental variables influence ecological attributes.

\section{Materials and Methods}

The Brazilian savanna, also known as "Cerrado", spans more than $2,000,000 \mathrm{~km}^{2}$, formerly covering $23 \%$ of the country's surface (Ratter et al. 1997). It is a vegetation mosaic composed by different vegetation types (Sano \& Almeida 1998), which harbor springs and major watersheds in Brazil (Padovesi-Fonseca 2006). We sampled 19 first and second orders streams (1:50.0000 scale, Strahler convention) near or within protected areas such as Serra da Bodoquena National Park, Emas National Park, and Serra da Canastra National Park, which belong to the upper portions of Paraguay, Paraná, and São Francisco river basins, respectively (Figure 1, Table 1).

Firstly, we defined streams conservation status based on the habitat physical integrity index (PHI, Barbour et al. 1999, adapted to headwaters of the Paraná river basin by Casatti et al. 2006) and the type of matrix that surrounded the stream. For that stream reaches were divided in 10 equidistant transects, in which habitat features such as width, depth, current velocity, flow, substrate composition were evaluated (according to Casatti et al. 2006). The phisico-chemical parameters (dissolved oxygen, turbidity, temperature and conductivity) were also obtained with Horiba ${ }^{\circledR}$ - U-10 model. Streams with the higher values of PHI and located within or close to conservation areas were considered the more preserved, whereas those with lower values of PHI and inserted in pasture areas or distant from protected areas were considered less preserved (Table 1).

Macroinvertebrates were sampled with a Surber net $\left(0.09 \mathrm{~m}^{2}\right.$ area, $250 \mu \mathrm{m}$ mesh) by washing the substrate within the sampler area for one minute. Six pseudoreplicates were taken in each main substrate type at each sampling site. The streams were sampled in September 2008 and in January 2009, with a total of 282 samples (102 in the Paraguay River basin, 90 in the Paraná, and 90 in the São Francisco). The material retained in the sampler was fixed in $10 \%$ formalin and later preserved in $70 \%$ ethanol. The specimens were sorted into taxonomic groups (orders or families) and specific keys were used for each group (Fernández \& Domingues 2001, Costa et al. 2006, Mugnai et al. 2010). Specialists confirmed the identification of all specimens and overall genera distributions were obtained in the reference literature.

The number of genera in each order was compared using a covariance analysis (ANCOVA, Underwood 1997), with the abundance used as covariate and basins and conservation status as categorical independent variables. The abundance was transformed with natural logarithm (Zar 1999). ANCOVA was conducted in the software Statistica 6.0 (Statsoft 2004), and the comparison between groups were conducted by the least square means tool. The alfa level adopted in this analysis was 0.01 .

To compare the community structure among basins we used a non-metric multidimensional scaling (nMDS) with clustering option. Complementarily, we conducted a similarity analysis (ANOSIM) to test whether species abundance was influenced by spatial variables (hydrographic basins) and conservation status (more and less protected areas). Species abundance was transformed using square root and the similarity matrix was extratected using the Bray Curtis coefficient. This analysis was conducted in the software Primer 6.0 (Clarke \& Gorley 2001).

We performed a partial linear regression to evaluate the proportion of variation in genera richness and abundance (response variables) explained by predictor variables. This analysis estimates how much of the variation in a response variable that can be assigned exclusively to one set of factors, taking into account the effect another set (Legendre $\&$ Legendre 1998). Two sets of predictive variables were considered: spatial (latitude and longitude) and environmental (instream diversity, size, flow, and physical habitat integrity index "PHI"). Previously, we removed environmental variables with VIF (variance inflaction factor) higher than 10 , since VIF $\geq 10$ indicates high correlation among predictive variables (Quin \& Keough 2002). This analysis was conducted in the software SAM v4.0 (Rangel et al. 2010).

\section{Results}

Overall, 2,728 specimens of aquatic insects were collected in 282 samples, belonging to 21 families and 62 genera (Appendix 1, 2 and 3 ). The percentage of insect orders was similar in the three basins, with the predominance of Ephemeroptera in all of them. The mayfly families Baetidae and Leptophlebiidae were also the most abundant in all basins, representing more than $80 \%$ of the material sampled. The genus Americabaetis was the most abundant in the Paraguay and São Francisco basins. The caddisfly Hydropsychidae was the most abundant family in the Paraná and São Francisco basins, whereas the Calamoceratidae was the most abundant family in the Paraguay basin. The Paraná basin had low abundances of all genera collected.

Plecoptera and Ephemerptera richness did not vary in the three basins, though São Francisco streams showed the highest Trichoptera 


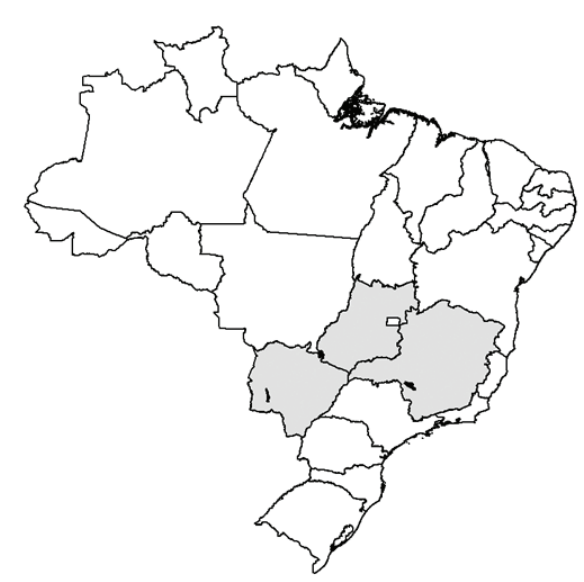
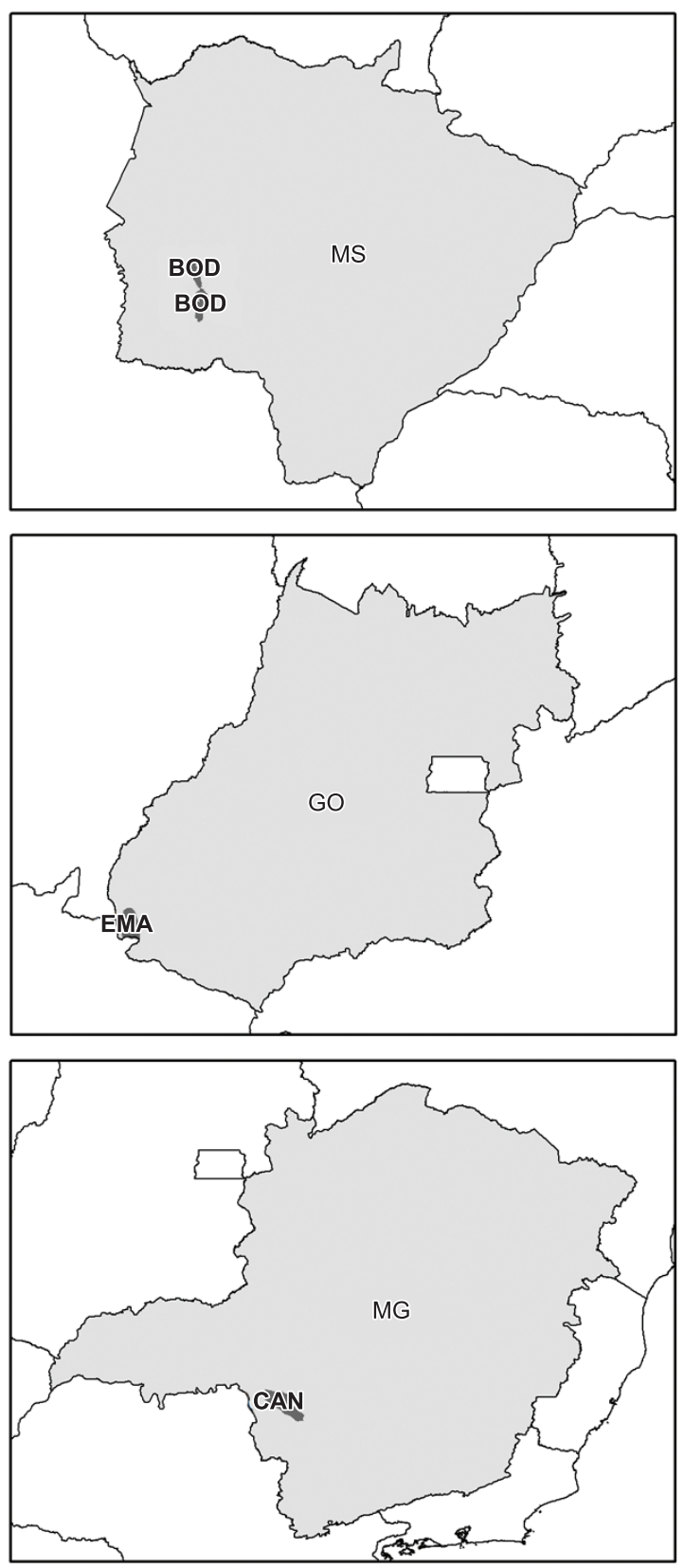<smiles>NC(N)CS</smiles>
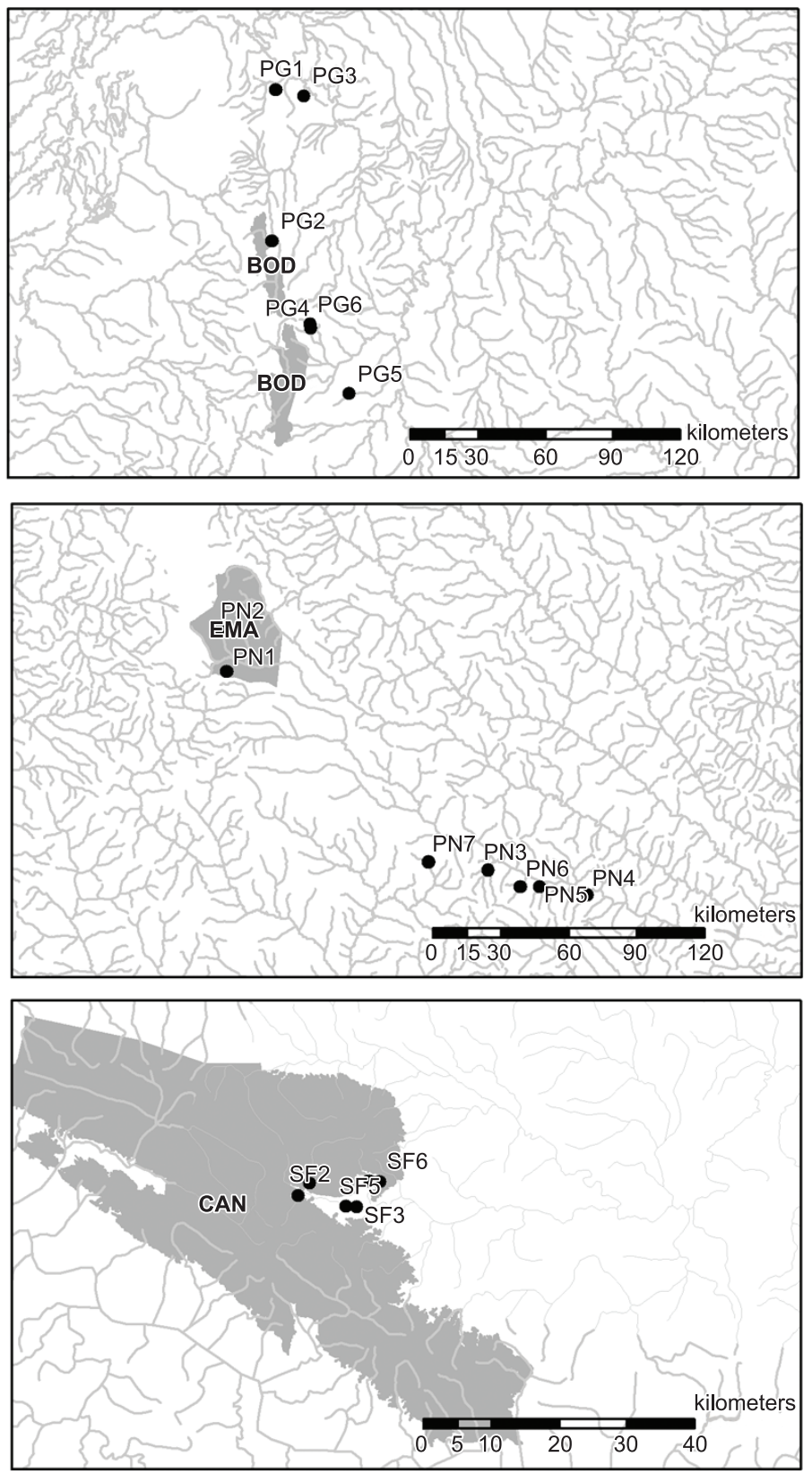

Figure 1. Stream reaches sampled in the Paraguay (PG), Paraná (PN), and São Francisco (SF) river basins, Brazil. BOD, Serra da Bodoquena National Park (MS State), MPE, Emas National Park (GO State), CAN, Serra da Canastra National Park (MG State). 
genus richness. With regards to conservation status we did not find differences in Tricoptera and Plecoptera richness, though the less preserved areas presented higher richness of Ephemeroptera genera (Table 2). The pattern of genera distribution was significantly different among the three basins $(\mathrm{R}=0.336, \mathrm{p}=0.001)$ (Figure 2$)$, evidencing their distinct patterns of composition, but differences in status of conservation were not significant $(R=-0.039, p=0.737)$.

The regression model evidenced that genera richness was significantly explained by the set of predictive variables (Table 3 ). Nonetheless, the latitude explained most of the variation in genera

Table 1. Stream codes, location, surroundings, mean width (m), mean depth (m), and geographical coordinates of the sampling sites in the Paraguay (PG), Paraná (PN), and São Francisco (SF) river basins. MS = Mato Grosso do Sul State, MG = Minas Gerais State, NP = National Park.

\begin{tabular}{|c|c|c|c|c|c|c|}
\hline Codes & Stream/city/State & Surroundings & $\begin{array}{l}\text { Mean width } \\
(\mathrm{m})\end{array}$ & $\begin{array}{l}\text { Mean depth } \\
(\mathrm{cm})\end{array}$ & $\begin{array}{l}\text { Physical habitat } \\
\text { integrity (PHI) }\end{array}$ & $\begin{array}{l}\text { Geographical } \\
\text { coordinates }\end{array}$ \\
\hline PG1 & Azul/Bodoquena/MS & NP Bodoquena & 9.4 & 54.1 & 159 & $\begin{array}{l}20^{\circ} 45^{\prime} 31,3 ” \mathrm{~S} \\
56^{\circ} 45^{\prime} 06,8^{\prime \prime} \mathrm{W}\end{array}$ \\
\hline PG2 & Santa Maria/Bodoquena/MS & NP Bodoquena & 9.5 & 35 & 161 & $\begin{array}{l}20^{\circ} 41^{\prime} 06,2 ” \mathrm{~S} \\
56^{\circ} 46^{\prime} 40,4, \mathrm{~W}\end{array}$ \\
\hline PG3 & Taquaral/Bonito/MS & NP Bodoquena & 6.4 & 32.2 & 177 & $\begin{array}{l}20^{\circ} 06^{\prime} 13,7^{\prime \prime} \mathrm{S} \\
56^{\circ} 38^{\prime} 00,3 ” \mathrm{~W}\end{array}$ \\
\hline PG4 & Seco/Bonito/MS & Pasture & 5.1 & 34.7 & 140 & $\begin{array}{l}21^{\circ} 02^{\prime}, 06,4^{\prime \prime} \mathrm{S} \\
56^{\circ} 36^{\prime} 53,7^{\prime \prime} \mathrm{W}\end{array}$ \\
\hline PG5 & Mutum/Bonito/MS & Pasture & 5.5 & 36 & 113 & $\begin{array}{l}21^{\circ} 18^{\prime} 01,1^{\prime \prime} \mathrm{S} \\
56^{\circ} 26^{\prime} 07,7^{\prime \prime} \mathrm{W}\end{array}$ \\
\hline PG6 & Olaria/Bonito/MS & Pasture & 3 & 34 & 145 & $\begin{array}{l}21^{\circ} 01^{\prime}, 46,99^{\prime \prime} \mathrm{S} \\
56^{\circ} 36^{\prime} 56,5 ” \mathrm{~W}\end{array}$ \\
\hline PN1 & Glória/Chapadão do Céu/MS & NP Emas & 1.1 & 35 & 158 & $\begin{array}{l}18^{\circ} 17^{\prime} 49,66^{\prime \prime} \mathrm{S} \\
52^{\circ} 58^{\prime} 33,2 ” \mathrm{~W}\end{array}$ \\
\hline PN2 & $\begin{array}{l}\text { Água Amarela/Chapadão do } \\
\text { Céu/MS }\end{array}$ & NP Emas & 1.1 & 44.5 & 165 & $\begin{array}{l}18^{\circ} 07^{\prime} 57,7^{\prime \prime} \mathrm{S} \\
53^{\circ} 00^{\prime} 33,0 \prime \mathrm{W}\end{array}$ \\
\hline PN3 & Galheiros/Cassilândia/MS & Preservation area & 2.7 & 49.7 & 145 & $\begin{array}{l}19^{\circ} 05^{\prime} 11,9^{\prime \prime} \mathrm{S} \\
51^{\circ} 53^{\prime} 06,2 \mathrm{~W}\end{array}$ \\
\hline PN4 & Grande MS/Cassilândia/MS & Pasture & 5.6 & 51.3 & 69 & $\begin{array}{l}19^{\circ} 11^{\prime} 16,8^{\prime \prime} \mathrm{S} \\
51^{\circ} 28^{\prime} 29,8^{\prime \prime} \mathrm{W}\end{array}$ \\
\hline PN5 & Ritinha/Cassilândia/MS & Pasture & 4.5 & 35 & 59 & $\begin{array}{l}19^{\circ} 09^{\prime} 48,6 " \mathrm{~S} \\
51^{\circ} 40^{\prime} 09,6 \text { " } \mathrm{W}\end{array}$ \\
\hline PN6 & Cedro/Cassilândia/MS & Pasture & 2.5 & 50 & 87 & $\begin{array}{l}19^{\circ} 09^{\prime} 11,8^{\prime \prime} \mathrm{S} \\
51^{\circ} 45^{\prime} 00,7^{\prime \prime} \mathrm{W}\end{array}$ \\
\hline PN7 & Indaiazinho/Cassilândia/MS & Pasture & 5.7 & 30.6 & 115 & $\begin{array}{l}19^{\circ} 03^{\prime} 00,2^{\prime \prime} \mathrm{S} \\
52^{\circ} 08^{\prime} 54,6 " \mathrm{~W}\end{array}$ \\
\hline SF1 & $\begin{array}{l}\text { Luciano/São Roque de Minas/ } \\
\text { MG }\end{array}$ & NP Canastra & 8.7 & 26.5 & 152 & $\begin{array}{l}20^{\circ} 18^{\prime} 46,5 ” \mathrm{~S} \\
46^{\circ} 31,46,5 ” \mathrm{~W}\end{array}$ \\
\hline SF2 & $\begin{array}{l}\text { Cachoeirinha/São Roque de } \\
\text { Minas/MG }\end{array}$ & Reserve & 9.1 & 50 & 147 & $\begin{array}{l}20^{\circ} 19^{\prime} 27,3 \prime \mathrm{S} \\
46^{\circ} 32^{\prime} 15,3 ” \mathrm{~W}\end{array}$ \\
\hline SF3 & $\begin{array}{l}\text { Grande MG/São Roque de } \\
\text { Minas/MG }\end{array}$ & Reserve & 6 & 26.9 & 147 & $\begin{array}{l}20^{\circ} 20^{\prime} 25^{\prime \prime} \mathrm{S} \\
46^{\circ} 27^{\prime} 56,2^{\prime \prime} \mathrm{W}\end{array}$ \\
\hline SF4 & $\begin{array}{l}\text { Mandioca/São Roque de Minas/ } \\
\text { MG }\end{array}$ & Pasture & 3.6 & 27.3 & 126 & $\begin{array}{l}20^{\circ} 18^{\prime}, 52,6 ” \mathrm{~S} \\
46^{\circ} 26^{\prime} 22,3 ” \mathrm{~W}\end{array}$ \\
\hline SF5 & $\begin{array}{l}\text { Cerrado/São Roque de Minas/ } \\
\text { MG }\end{array}$ & Pasture & 4.3 & 34.5 & 131 & $\begin{array}{l}20^{\circ} 20^{\prime} 00,0 ” \mathrm{~S} \\
46^{\circ} 28^{\prime} 30,6^{\prime \prime} \mathrm{W}\end{array}$ \\
\hline SF6 & Lavra/São Roque de Minas/MG & Pasture & 8.8 & 27.6 & 137 & $\begin{array}{l}20^{\circ} 18^{\prime}, 36,1 ” \mathrm{~S} \\
46^{\circ} 25,59,6 ” \mathrm{~W}\end{array}$ \\
\hline
\end{tabular}

Table 2. Results of ANCOVA for genera richness, with the abundance as a covariate, and river basin and status of conservation as the categorical independent variables. SS, sum of squares; DF, degree of freedom; F, statistical value; $p$, level of significance. Significant $p$ values were marked with *.

\begin{tabular}{|c|c|c|c|c|c|c|c|c|c|c|c|c|}
\hline \multirow{2}{*}{ Parameters } & \multicolumn{4}{|c|}{ Plecoptera } & \multicolumn{4}{|c|}{ Ephemeroptera } & \multicolumn{4}{|c|}{ Trichoptera } \\
\hline & SS & DF & $\mathbf{F}$ & $\mathbf{p}$ & SS & DF & $\mathbf{F}$ & $\mathbf{p}$ & SS & DF & $\mathbf{F}$ & $\mathbf{p}$ \\
\hline Intercept & 0.104 & 1 & 3.443 & 0.064 & 0.294 & 1 & 0.559 & 0.455 & 1.861 & 1 & 8.263 & $0.004 *$ \\
\hline Abundance & 33.789 & 1 & 1117.913 & $0.000 *$ & 567.021 & 1 & 1075.679 & $0.000 *$ & 192.483 & 1 & 854.285 & $0.000 *$ \\
\hline Basin & 0.024 & 2 & 0.411 & 0.663 & 0.658 & 2 & 0.625 & 0.536 & 2.524 & 2 & 5.602 & $0.004 *$ \\
\hline Status & 0.0009 & 1 & 0.030 & 0.861 & 3.603 & 1 & 6.835 & $0.009^{*}$ & 0.019 & 1 & 0.086 & 0.768 \\
\hline Basin $\times$ status & 0.0000 & 2 & 0.001 & 0.998 & 2.304 & 2 & 2.186 & 0.114 & 0.452 & 2 & 1.004 & 0.367 \\
\hline Error & 8.312 & 275 & & & 144.960 & 275 & & & 61.961 & 275 & & \\
\hline
\end{tabular}


richness $(p=0.004)$ and abundance $(p=0.026)$. Additionally, $55 \%$ of the variation in the number of genera was explained by environmental variables (Table 3 ), among which instream diversity was the most important $(\mathrm{p}=0.041)$.

\section{Discussion}

Biogeographic analyses for most tropical benthic macroinvertebrates are scarce, mainly due to taxonomic uncertainties and lack of regional studies. The percentage of insect orders and the dominance of the families Baetidae, Leptophlebiidae, and Helicopsychidae found herein followed the same general patterns of tropical streams (Jacobsen et al. 2008). Nevertheless, some families like Griptoterygidae, Glossosomatidae, Hydrobiosidae, Polycentropodidae, and Sericostomatidae occurred only in the São Francisco basin, whereas Coryphoridae, Polymitarcyidae, and Ecnomidae were restricted to the Paraguay basin. All members of these families occurred in low abundance, reinforcing their rarity.

The distribution of some genera was expanded. The genus Grumicha, only known from São Paulo and Santa Catarina states (Paprocki et al. 2004), now had their occurrence registered in the Minas Gerais State. The genera Coryphorus (known from Amapá and Pará states, Salles et al. 2004) and Austrotinodes (known from Amazonas, São Paulo, Minas Gerais, and Paraná states, Paprocki et al. 2004) were now recorded for Mato Grosso do Sul state, expanding the distribution of these genera.
The São Francisco basin, especially where the study was conducted, is characterized by streams with the predominance of runs and rapids, with a wide range of substrate types like gravel, little rocks and rocks as found by Casatti \& Castro (1998). This kind of gravelly substrate is an important source of resources to several macroinvertebrates, including those of the order Trichoptera (Flecker \& Allan 1984, Nolte et al. 1996, Kikuchi \& Uieda 1998, Duan et al. 2008), what may explain the higher richness of this group in this basin. In the three investigated groups of aquatic insects, only the number of Ephemeroptera genera was associated to stream conservation status. The higher number of mayfly genera was registered in the less preserved area, contrasting with other studies (e.g., Kerans \& Karr 1994, Compin \& Céréghino 2003, Baptista et al. 2007). These studies, in general, were conducted with the aim to compare streams along a conservation gradient, differently of those herein studied. The increased number of Ephemeroptera genera in less preserved streams was probably reflected their great habitat heterogeneity, which is typical of low disturbance condictions, like the sites studied by us. Additionally, the results derived from ANOSIM showed that the community structure was similar, independently of the conservation status, reinforcing the similarity in community structure of aquatic insects.

The low physical alterations observed in the less preserved areas, such as the few exposed riverbanks, some fragmentation and siltation points, and pasture surrounding the riparian vegetation, contributed

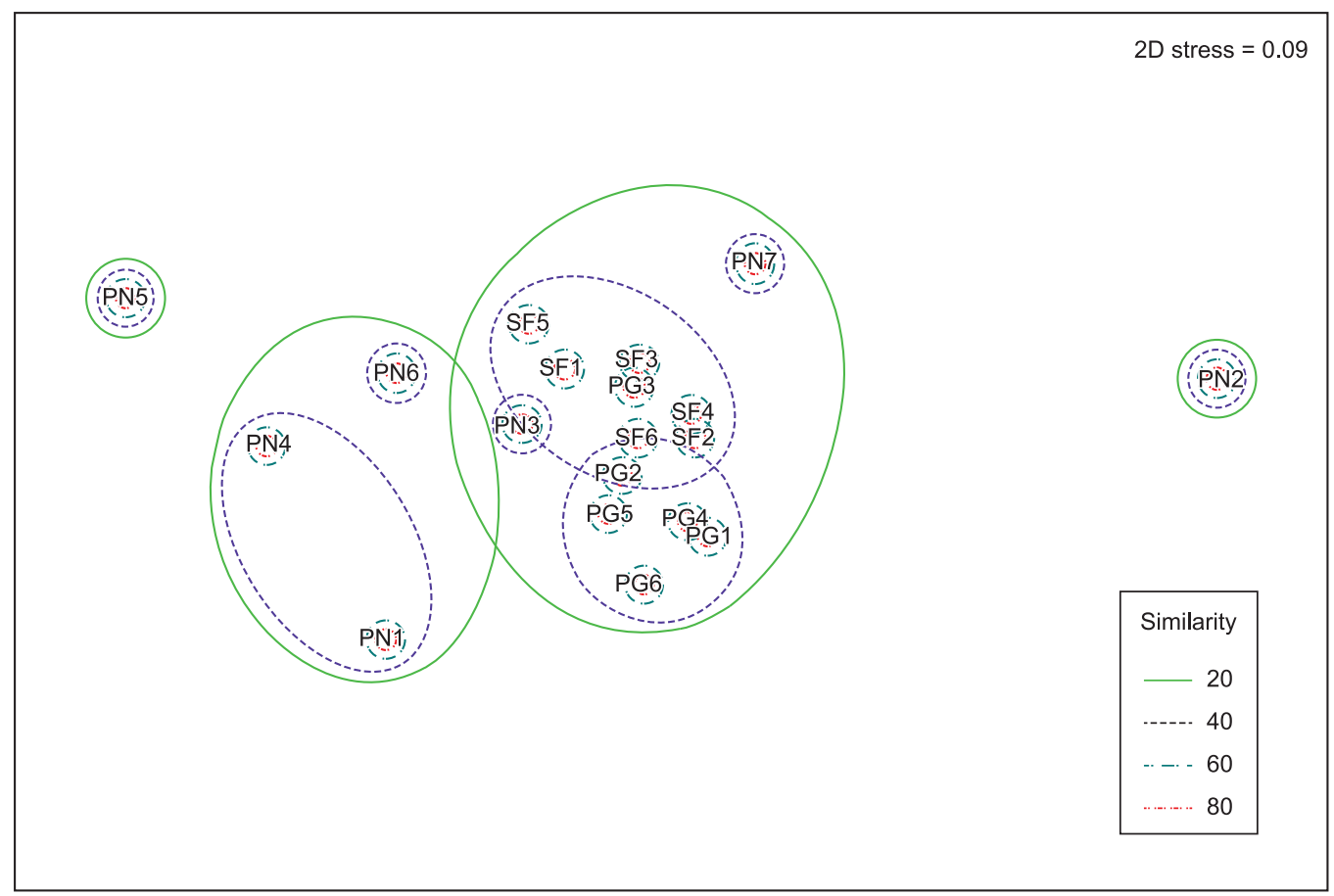

Figure 2. Two-dimensional projection of the axes from nMDS analysis, considering the abundance of genera and the groupings of more preserved transects (C) and less preserved (D) in the Paraguay (PG), Paraná (PN), and São Francisco (SF) river basins.

Table 3. Adjusted coefficient of determination $\left(\mathrm{R}^{2}\right)$, P-values, and variation in genera richness and abundance explained by each group of variables: (a) latitude and longitude, (b) instream diversity, size, flow, and physical habitat integrity index.

\begin{tabular}{|c|c|c|c|c|c|c|c|}
\hline \multirow{2}{*}{ Response variables } & \multirow{2}{*}{$\mathbf{n}$} & \multirow{2}{*}{$\mathbf{R}^{2}$} & \multirow{2}{*}{$\boldsymbol{P}$} & \multicolumn{4}{|c|}{ Proportion of variation explained $\left(R^{2}\right)$} \\
\hline & & & & $a$ & $b$ & $a+b$ & Residual \\
\hline Number of genera & 19 & 0.735 & $<0.001$ & 0.658 & 0.548 & 0.809 & 0.191 \\
\hline Abundance & 19 & 0.430 & 0.060 & 0.459 & 0.037 & 0.588 & 0.412 \\
\hline
\end{tabular}


to an intermediate value for the physical habitat integrity index (see Table 1) and possibly provided a very diverse instream habitat, one of the most important structuring factor affecting community richness, like proved by the partial regression. In addition, all streams presented riparian forests, even the less preserved ones; this vegetation directly influences the community structure of aquatic insects, mainly by the input of nutrients and allochthonous energy (Gonçalves-Junior et al. 2006a, b, Jacobsen et al. 2008).

The physical habitat integrity index remains a useful tool for physical disturbance characterization in lotic environments (Barbour et al. 1999, Casatti et al. 2006) and consists of a breakthrough on how to quantify impacts in these environments. However, if the aim is to distinguish between sampling groups, only areas with extreme index values should be used. Considering the taxonomic resolution of this study, we concluded that less impacted areas, or with diffuse impacts, apparently did not influence the aquatic insect communities enough to allow distinguishing areas according to impact degree. An improved taxonomic resolution (Olsgard et al. 1998) and the inclusion of other groups in the analysis (Callisto et al. 2004, Hodkinson \& Jackson 2005), along with the development of complete biotic indices (Baptista et al. 2007, Roche et al. 2010), could be other useful tools to discriminate between sites with different degrees of anthropogenic impacts.

In summary, community structure among river basins was significantly different, and latitude was identified as one of the most important factors that affect genus richness in these communities, reiforcing the influence of spatial attributes. Presumably, the geographic barriers separating the river basins prevent the migration of larvae and the distance between sampling sites probably limited a wide dispersion between areas; moreover, mayflies, stoneflies, and caddisflies have a short-lived winged adult stage and are not good dispersers (Sartori et al. 2000). Hence, the regional differences can be attributed to spatial influences, quantity or quality of habitats (Kay et al. 1999) and the original distribution of taxa within each basin (Jacobsen et al. 2008).

\section{Acknowledgements}

We thank the colleagues from Laboratório de Ictiologia for their help during fieldwork and the Departamento de Zoologia e Botânica IBILCE, UNESP for providing workspace, IBAMA for collecting permits, and landowners for allowing access to their properties. Gabriel L. Brejão helped with Figure 1. Diogo B. Provete helped with English language. Pitágoras C. Bispo and his team (Laboratory of Aquatic Biology, UNESP, Assis) helped with taxonomic identification. We are grateful to anonymous reviwers for important suggestion to improve the manuscript. This study was made possible by funding from FAPESP. RMR, MCB, GHB received fellowships from FAPESP and LC is a CNPq fellow.

\section{References}

ALLAN, J.D. 1995. Structure and function of running waters. Chapman \& Hall, London, 388p.

ARUNACHALAM, M.K., NAIR, K.C.M., VIJVERBERG, J., KORTMULDER, K. \& SURIYANARAYNAN, H. 1991. Substrate selection and seasonal variation in densities of invertebrates in stream pools of a tropical river. Hydrobiology 213:141-148. http://dx.doi. org/10.1007/BF00015000

AYRES-PERES, L., SOCOLOWICZ, C. \& SANTOS, S. 2006. Diversity and abundance of the benthic macrofauna in lotic environments from the central region of Rio Grande do Sul State, Brazil. Biota Neotrop. 6(3):1-11. http://www.biotaneotropica.org.br/v6n3/pt/ abstract?article+bn02106032006 (último acesso em 20/01/2012)
BAPTISTA, D.F., BUSS, D.F., EGLER, M., GIOVANELLI, A., SILVEIRA, M.P \& NESSIMIAN, J. 2007. A multimetric index based on benthic macroinvertebrates for evaluation of Atlantic Forest streams at Rio de Janeiro state, Brazil. Hydrobiol. 575(1):83-94. http://dx.doi.org/10.1007/ s10750-006-0286-x

BARBOSA, F.A.R., CALLISTO, M. \& GALDEAN, N. 2001. The diversity of benthic macroinvertebrates as an indicator of water quality and ecosystem health: a case study for Brazil. Aquat. Ecosyst. Health 4:51-59. http:// dx.doi.org/10.1080/146349801753569270

BARBOUR, M.T., GERRITSEN, J., SNIDER, B.D. \& STRIBLING, J.B. 1999. Rapid bioassessment protocols for use in streams and wadeable rivers: periphyton, benthic macroinvertebrates and fish. EPA 841-B-99002, U. S. Environmental Protection Agency, Washington.

BEAUCHARD, O., GAGNEUR, J. \& BROSSE, S. 2003. Macroinvertebrate richness patterns in North African streams. J. Biogeog. 30:1821-1833. http://dx.doi.org/10.1111/j.1365-2699.2003.00954.x

BUSS, D.F., BAPTISTA, D.F., SILVEIRA, M.P., NESSIMIAN, J.L. \& DORVILLÉ, L.F.M. 2002. Influence of water chemistry and environmental degradation on macroinvertebrates assemblages in a river basin in south-east Brazil. Hydrobiology 481(1-3):125-136. http://dx.doi. org/10.1023/A:1021281508709

BUSS, D.F., BAPTISTA, D.F., NESSIMIAN, J.L. \& EGLER, M. 2004. Substrate specificity, environmental degradation and disturbance structuring macroinvertebrate assemblages in neotropical streams. Hydrobiology 518(1-3):179-188. http://dx.doi.org/10.1023/ B:HYDR.0000025067.66126.1c

CAIRNS, J. \& PRATT, J.R. 1993. A history of biological monitoring using benthic macroinvertebrates. In Freshwater biomonitoring and benthic macroinvertebrates (D.M. Rosenberg \& V.R. Resh, eds.). Chapman \& Hall, New York, p.10-27.

CALLISTO, M., GOULART, M., MEDEIROS, A.O., MORENO, P. \& ROSA, C.A. 2004. Diversity assessment of benthic macroinvertebrates, yeasts, and microbiological indicators along a longitudinal gradient in Serra do Cipó, Brazil. Braz. J. Biol. 64(4):743-755.

CASATTI, L. \& CASTRO, R.M.C. 1998. A fish community from the headwaters of the São Francisco river, southeastern Brazil. Ichttyol. Explor. Freshw. 9(3):229-242.

CASATTI, L., SILVA, A.M., LANGEANI, F. \& CASTRO, R.M.C. 2006. Stream fishes, water and habitat quality in a pasture dominated basin, Southeastern Brazil. Braz. J. Biol. 66:681-696. http://dx.doi.org/10.1590/ S1519-69842006000400012

CLARKE, K. R. \& GORLEY, R. N. 2001. PRIMER v5: User manual/tutorial. PRIMER-E, Plymouth.

COSTA, C., IDE, S. \& SIMONKA, C.E. 2006. Insetos imaturos: metamorfose e identificação. Holos, Ribeirão Preto, 249p.

COMPIN, A. \& CÉRÉGHINO, R. 2003. Sensitivity of aquatic insect species richness to disturbance in the Adour-Garonne stream system (France). Ecol. Indic. 3:135-142. http://dx.doi.org/10.1016/S1470$160 \mathrm{X}(03) 00016-5$

DUAN, X., WANG, Z. \& TIAN, S. 2008. Effect of streambed substrate on macroinvertebrate biodiversity. Front. Env. Sci. Eng. China 2(1):122-128. http://dx.doi.org/10.1007/s11783-008-0023-y

FERNÁNDEZ, H.R. \& DOMINGUES, E. 2001. Guía para la determinación de los artrópodos bentônicos sudamericanos. San Miguel de Tucumán, Secretaría de Ciencia y técnica de la Universidad Nacional de Tucumán, 282p.

FLECKER, A.S \& ALLAN, J.D. 1984. The importance of predation, substrate and spatial refugia in determining lotic insect distributions. Oecologia 64(3): 306-313. http://dx.doi.org/10.1007/BF00379126

GALDEAN, N., CALlisto, M. \& BARBOSA, F.A.R. 2000. Lotic ecosystems of Serra do Cipó, southeast Brazil: water quality and a tentative classification based on the benthic macroinvertebrate community. Aquat. Ecosyst. Health 3:545-552. http://dx.doi. org/10.1080/14634980008650691 
GONÇALVES-JUNIOR, J.F., FRANÇA, J.S., MEDEIROS, A. O., ROSA, C.A. \& CALLISTO, M. 2006a. Leaf breakdown in a tropical stream. Int. Rev. Hydrobiol. 91:164-177. http://dx.doi.org/10.1002/iroh.200510826

GONÇALVES-JUNIOR, J.F., GRAÇA, M.A.S \& CALLISTO, M. $2006 \mathrm{~b}$. Leaf-litter breakdown in 3 streams in temperate, Mediterranean, and tropical Cerrado climates. J. N. Am. Benthol. Soc. 25(2):344-355. http:// dx.doi.org/10.1899/0887-3593(2006)25[344:LBISIT]2.0.CO;2

HODKINSON, I. D. \& JACKSON, J. K. 2005. Terrestrial and aquatic invertebrates as bioindicators for environmental monitoring, with particular reference to mountain ecosystems. Env. Manag. 35(5):649-666. http://dx.doi.org/10.1007/s00267-004-0211-x

HYNES, H.B.N. 1970. The ecology of running waters. Liverpool University Press, Liverpool, 555p.

JACOBSEN, D., CRESSA, C., MATHOOKO, J. M. \& DUDGEON, D. 2008. Macroinvertebrates: composition, life histories and production. In Tropical stream ecology (D. Dudgeon, ed.). Elsevier, San Diego, p.65105. http://dx.doi.org/10.1016/B978-012088449-0.50006-6

KARR, J.R. 1991. Biological integrity: a long-neglected aspect of water resource management. Ecol. Appl. 1:66-84. http://dx.doi. org $/ 10.2307 / 1941848$

KAY, W.R., SMITH, M.J., PINDER, A.M., McRAE, J.M., DAVIS, J.A. \& HALSE, S.A. 1999. Patterns of distribution of macroinvertebrate families in rivers of north-western Australia. Fresh. Biol. 41:299-316. http://dx.doi. org/10.1046/j.1365-2427.1999.00432.x

KERANS, B.L. \& KARR, J.R. 1994. A benthic index of biotic integrity (B-IBI) for rivers of the Tennessee Valley. Ecol. Appl. 4(4):768-785. http://dx.doi.org/10.2307/1942007

KIKUCHI, R.M. \& UIEDA, V.S. 1998. Composição da comunidade de invertebrados de um ambiente lótico tropical e sua variação espacial e temporal. In Ecologia de insetos aquáticos (J.L. Nessimian \& A.L. Carvalho, eds). PPGE-UFRJ, Rio de Janeiro, v.5, p.157-173. Série Oecologia Brasiliensis.

LEGENDRE, P. \& LEGENDRE, L. 1998. Numerical ecology. Elsevier, Amsterdam, 853p.

MARQUES, M. \& BARBOSA, F. 2001. Biological quality of waters from an impacted tropical watershed (middle Rio Doce basin, southeast Brazil), using benthic macroinvertebrate communities as an indicator. Hydrobiology 457:69-76. http://dx.doi.org/10.1023/A:1012297915323

MERRITT, R.W. \& CUMMINS, K.W. 1984. An introduction to the aquatic insects of North America. Dubuque, Kendall/Hunt, Iowa, 722p.

MILESI, S.V., BIASI, C., RESTELLO, R.M. \& HEPP, L.U. 2009. Distribution of benthic macroinvertebrates in Subtropical streams (Rio Grande do Sul, Brazil). Acta Limnol. Bras. 21(4):419-429.

MORETTI, M.S. \& CALLISTO, M. 2005. Biomonitoring of benthic macroinvertebrates in the middle Doce River watershed. Acta Limnol. Bras. 17(3):267-281.

MUGNAI, R., NESSIMIAN, J.L. \& BAPTISTA, D.F. 2010. Manual de identificação de macroinvertebrados aquáticos do estado do Rio de Janeiro. Technical Books Editora, Rio de Janeiro, 174p.
NOLTE, U., TIETBÖHL, R.S. \& McCAFFERTY, W.P. 1996. A mayfly from tropical Brazil capable of tolerating short-term dehydration. J. N. Am. Benthol. Soc. 15:87-94. http://dx.doi.org/10.2307/1467434

OLSGARD, F., SOMERFIELD, P.J. \& CARR, M.R. 1998. Relationships between taxonomic resolution, macrobenthic community patterns and disturbance. Mar. Ecol. Progr. Ser. 172:25-36. http://dx.doi.org/10.3354/ meps 172025

QUIN, G.P. \& KEOUGH, M.J. 2002. Experimental design and data analysis for biologists. Cambridge University Press, New York, 537p. http://dx.doi. org $/ 10.1017 / \mathrm{CBO} 9780511806384$

PADOVESI-FONSECA, C. 2006. Caracterização dos ecossistemas aquáticos do Cerrado. In Cerrado: Ecologia, Biodiversidade e Conservação (A. Scariot, J.C. Souza-Silva \& J.M. Felfili, eds.). Ministério do Meio Ambiente, Brasília, p.415-429.

PAPROCKI, H., HOLZENTHAL, R.W. \& BLAHNIK, R.J. 2004. Checklist of the Trichoptera (Insecta) of Brazil I. Biota Neotrop. 4(1): 1-22 http://www. biotaneotropica.org.br/v4n1/pt/abstract?inventory+BN01204012004 (último acesso em 20/01/2012)

RANGEL, T.F., DINIZ-FILHO, J.A.F. \& BINI, L.M. 2010. SAM: a comprehensive application for spatial analysis in macroecology. Ecography 33:46-50. http://dx.doi.org/10.1111/j.1600-0587.2009.06299.x

RATTER, J.A., RIBEIRO, J.F. \& BRIDGEWATER, S. 1997. The Brazilian Cerrado vegetation and threats to its biodiversity. Ann. Bot. 80:223-230. http://dx.doi.org/10.1006/anbo.1997.0469

RESH, V.H. \& ROSENBERG, D.M. 1984. The ecology of aquatic insects. Praeger Publishers, New York, 625p.

ROCHE, K.F., QUEIRO, E.P., RIGHI, K.O. \& SOUZA, G.M. 2010. Use of the BMWP and ASPT indexes for monitoring environmental quality in a neotropical stream. Acta Limnol. Brasil. 22(1):105-108. http://dx.doi. org/10.4322/actalb.02201010

SALLES, F.F., DA-SILVA, E.R., HUBBARD, M.D. \& SERRÃO, J.E. 2004. As espécies de Ephemeroptera (Insecta) registradas para o Brasil. Biota Neotrop. 4(2): 1-34 http://www.biotaneotropica.org.br/v4n2/pt/abstract ?inventory+BN04004022004 (último acesso em 20/01/2012)

SANO, S.M. \& ALMEIDA, S.P. 1998. Cerrado: ambiente e flora. Editora Embrapa, Planaltina, 556p.

SARTORI, M., GATTOLLIAT, J., OLIARINONY, R. \& ELOUARD, J. 2000. Biogeography of malagasy mayflies (Insecta, Ephemeroptera): Preliminary results. In Diversité et endemisme a Madagascar (W.R. Lourenço \& S.M. Goodman, eds.). Memoires de La Sociétê de Biogéographie, Paris, p. 307-317.

SILVEIRA, M.P., BUSS, D.F., NESSIMIAN, J.L. \& BAPTISTA, D.F. 2006. Spatial and temporal distribution of benthic macroinvertebrates in southeastern Brazilian river. Braz. J. Biol. 66(2B):623-632. http://dx.doi. org/10.1590/S1519-69842006000400006

STATSOFT. 2004. Statistica (data analysis software system). version 6 .

UNDERWOOD, A.J. 1997. Experiments in ecology: Their logical design and interpretation using analysis of variance. Cambridge University Press, Cambridge.

ZAR, J.H. 1999. Biostatistical analysis. 4th ed. Prentice-Hall, New Jersey. 


\section{Appendix}

Appendix 1. List of Ephemeroptera, Plecoptera, and Trichoptera sampled in each of the six streams from the Paraguay River basin (PG 1-6). The geographical distribution of species marked with * was expanded.

\begin{tabular}{|c|c|c|c|c|c|c|c|}
\hline Order/family & Taxa & PG1 & PG2 & PG3 & PG4 & PG5 & PG6 \\
\hline \multicolumn{8}{|l|}{ Ephemeroptera } \\
\hline \multicolumn{8}{|l|}{ Baetidae } \\
\hline & Americabaetis & 7 & 13 & 144 & 24 & 1 & 2 \\
\hline & Camelobaetidius & 5 & 5 & 1 & 2 & 1 & 0 \\
\hline & Cloeodes & 0 & 0 & 0 & 0 & 0 & 3 \\
\hline & Waltzoyphius & 6 & 2 & 4 & 5 & 7 & 4 \\
\hline \multicolumn{8}{|l|}{ Leptohyphidae } \\
\hline & Leptohyphes & 2 & 2 & 1 & 4 & 3 & 0 \\
\hline & Macunahyphes & 1 & 0 & 0 & 0 & 0 & 0 \\
\hline & Traverhyphes & 38 & 1 & 11 & 47 & 35 & 0 \\
\hline & Cercobrachys & 0 & 0 & 0 & 0 & 1 & 0 \\
\hline \multicolumn{8}{|l|}{ Leptophlebiidae } \\
\hline & Farrodes & 0 & 7 & 7 & 8 & 3 & 4 \\
\hline & Leptophlebiidae type 1 & 0 & 0 & 0 & 1 & 0 & 4 \\
\hline & Hagenulopsis & 21 & 14 & 14 & 50 & 7 & 23 \\
\hline & Massartela & 0 & 0 & 0 & 0 & 0 & 3 \\
\hline & Miroculis & 2 & 4 & 0 & 15 & 4 & 19 \\
\hline & Simothraulopsis & 1 & 0 & 0 & 0 & 0 & 0 \\
\hline & Terpides & 39 & 0 & 0 & 48 & 2 & 5 \\
\hline & Thraulodes & 114 & 0 & 0 & 20 & 1 & 6 \\
\hline & Ulmeritoides & 1 & 1 & 0 & 132 & 3 & 31 \\
\hline \multicolumn{8}{|l|}{ Polymitarcyidae } \\
\hline & Anacroneuria & 4 & 4 & 1 & 6 & 3 & 2 \\
\hline & Macrogynoplax & 0 & 0 & 0 & 1 & 0 & 2 \\
\hline \multicolumn{8}{|l|}{ Trichoptera } \\
\hline \multicolumn{8}{|l|}{ Hydropsychidae } \\
\hline & Hydropsychidae type 1 & 0 & 0 & 0 & 0 & 0 & 1 \\
\hline & Leptonema & 2 & 1 & 4 & 0 & 0 & 1 \\
\hline & Macronema & 0 & 1 & 7 & 0 & 0 & 0 \\
\hline & Smicridea & 3 & 10 & 65 & 26 & 3 & 9 \\
\hline \multicolumn{8}{|l|}{ Policentropodidae } \\
\hline & Cyrnellus & 3 & 0 & 0 & 3 & 0 & 0 \\
\hline & Polycentropus & 2 & 0 & 0 & 0 & 0 & 2 \\
\hline \multicolumn{8}{|l|}{ Philopotamidae } \\
\hline & Chimarra & 35 & 21 & 0 & 12 & 0 & 0 \\
\hline \multicolumn{8}{|l|}{ Odontoceridae } \\
\hline & Barypenthus & 4 & 0 & 0 & 0 & 0 & 0 \\
\hline & Marilia & 0 & 1 & 0 & 0 & 0 & 3 \\
\hline \multicolumn{8}{|l|}{ Helicopsychidae } \\
\hline & Helicopsyche & 0 & 2 & 6 & 4 & 2 & 0 \\
\hline
\end{tabular}


Appendix 1. Continued...

\begin{tabular}{|c|c|c|c|c|c|c|c|}
\hline Order/family & Taxa & PG1 & PG2 & PG3 & PG4 & PG5 & PG6 \\
\hline \multicolumn{8}{|l|}{ Trichoptera } \\
\hline \multicolumn{8}{|l|}{ Leptoceridae } \\
\hline & Nectopsyche & 1 & 0 & 0 & 2 & 4 & 1 \\
\hline & Oecetis & 0 & 0 & 6 & 2 & 0 & 1 \\
\hline & Triplectides & 0 & 3 & 0 & 1 & 0 & 4 \\
\hline \multicolumn{8}{|l|}{ Calamoceratidae } \\
\hline & Phylloicus & 25 & 24 & 0 & 141 & 2 & 67 \\
\hline \multicolumn{8}{|l|}{ Ecnomidae } \\
\hline & Austrotinodes* & 0 & 0 & 1 & 0 & 5 & 0 \\
\hline \multicolumn{8}{|l|}{ Hydroptilidae } \\
\hline & Neotrichia & 0 & 0 & 9 & 1 & 0 & 0 \\
\hline & Rhyacopsyche & 0 & 0 & 0 & 0 & 0 & 1 \\
\hline Richness & & 22 & 20 & 16 & 26 & 22 & 26 \\
\hline Abundance & & 319 & 118 & 284 & 605 & 93 & 283 \\
\hline
\end{tabular}

Appendix 2. List of Ephemeroptera, Plecoptera, and Trichoptera sampled in each of the seven streams from the Paraná River basin (PN 1-7).

\begin{tabular}{|c|c|c|c|c|c|c|c|c|}
\hline Order/family & Genera & PN1 & PN2 & PN3 & PN4 & PN5 & PN6 & PN7 \\
\hline \multicolumn{9}{|l|}{ Ephemeroptera } \\
\hline \multicolumn{9}{|l|}{ Baetidae } \\
\hline & Americabaetis & 0 & 0 & 1 & 1 & 1 & 2 & 0 \\
\hline & Apobaetis & 0 & 0 & 0 & 0 & 0 & 1 & 1 \\
\hline & Aturbina & 0 & 0 & 2 & 0 & 0 & 1 & 5 \\
\hline & Baetodes & 0 & 0 & 3 & 0 & 0 & 0 & 4 \\
\hline & Camelobaetidius & 0 & 0 & 0 & 0 & 0 & 0 & 6 \\
\hline & Baetidae type 2 & 0 & 0 & 6 & 1 & 1 & 0 & 0 \\
\hline & Waltzoyphius & 0 & 0 & 4 & 0 & 0 & 0 & 8 \\
\hline & Zeluzia & 0 & 0 & 1 & 0 & 0 & 3 & 0 \\
\hline \multicolumn{9}{|l|}{ Leptohyphidae } \\
\hline & Macunahyphes & 0 & 0 & 0 & 0 & 0 & 0 & 2 \\
\hline & Traverhyphes & 0 & 0 & 0 & 0 & 0 & 1 & 0 \\
\hline & Tricorythopsis & 0 & 0 & 0 & 0 & 0 & 0 & 7 \\
\hline \multicolumn{9}{|l|}{ Caenidae } \\
\hline & Caenis & 0 & 0 & 1 & 0 & 0 & 0 & 0 \\
\hline \multicolumn{9}{|l|}{ Leptophlebiidae } \\
\hline & Farrodes & 5 & 0 & 5 & 7 & 0 & 10 & 0 \\
\hline & Thraulodes & 5 & 0 & 4 & 0 & 0 & 0 & 0 \\
\hline & Ulmeritus & 0 & 0 & 4 & 0 & 0 & 0 & 0 \\
\hline \multicolumn{9}{|l|}{ Plecoptera } \\
\hline \multicolumn{9}{|l|}{ Perlidae } \\
\hline & Anacroneuria & 0 & 0 & 5 & 0 & 0 & 0 & 0 \\
\hline & Macrogynoplax & 0 & 2 & 0 & 0 & 0 & 0 & 1 \\
\hline \multicolumn{9}{|l|}{ Trichoptera } \\
\hline \multicolumn{9}{|l|}{ Hydropsychidae } \\
\hline & Leptonema & 0 & 0 & 2 & 0 & 0 & 0 & 0 \\
\hline & Macronema & 0 & 0 & 2 & 0 & 0 & 0 & 0 \\
\hline & Smicridea & 0 & 0 & 5 & 0 & 0 & 1 & 27 \\
\hline \multicolumn{9}{|l|}{ Philopotamidae } \\
\hline & Chimarra & 0 & 0 & 0 & 0 & 0 & 1 & 0 \\
\hline \multicolumn{9}{|l|}{ Odontoceridae } \\
\hline & Marilia & 0 & 0 & 0 & 0 & 0 & 2 & 0 \\
\hline \multicolumn{9}{|l|}{ Helicopsychidae } \\
\hline & Helicopsyche & 0 & 0 & 0 & 0 & 0 & 0 & 3 \\
\hline
\end{tabular}


Appendix 2. Continued...

\begin{tabular}{|c|c|c|c|c|c|c|c|c|}
\hline Order/family & Genera & PN1 & PN2 & PN3 & PN4 & PN5 & PN6 & PN7 \\
\hline \multicolumn{9}{|l|}{ Trichoptera } \\
\hline \multicolumn{9}{|l|}{ Leptoceridae } \\
\hline & Grumichela & 2 & 0 & 0 & 1 & 0 & 0 & 0 \\
\hline & Nectopsyche & 1 & 0 & 0 & 0 & 0 & 0 & 0 \\
\hline & Oecetis & 1 & 0 & 0 & 0 & 0 & 0 & 0 \\
\hline & Triplectides & 1 & 0 & 0 & 0 & 0 & 0 & 0 \\
\hline \multicolumn{9}{|l|}{ Calamoceratidae } \\
\hline & Phylloicus & 1 & 0 & 0 & 0 & 0 & 0 & 0 \\
\hline Richness & & 7 & 1 & 14 & 4 & 2 & 9 & 10 \\
\hline Abundance & & 16 & 2 & 45 & 10 & 2 & 22 & 64 \\
\hline
\end{tabular}

Appendix 3. List of Ephemeroptera, Plecoptera, and Trichoptera sampled in each of the six streams from the São Francisco River basin (SF 1-6). The geographical distribution of species marked with * was expanded.

\begin{tabular}{|c|c|c|c|c|c|c|c|}
\hline Order/family & Genera & SF1 & SF2 & SF3 & SF4 & SF5 & SF6 \\
\hline \multicolumn{8}{|l|}{ Ephemeroptera } \\
\hline \multicolumn{8}{|l|}{ Baetidae } \\
\hline & Americabaetis & 1 & 0 & 39 & 88 & 35 & 10 \\
\hline & Apobaetis & 0 & 0 & 0 & 12 & 8 & 0 \\
\hline & Aturbina & 0 & 0 & 0 & 1 & 0 & 0 \\
\hline & Baetodes & 7 & 5 & 13 & 5 & 3 & 4 \\
\hline & Camelobaetidius & 0 & 1 & 1 & 3 & 0 & 10 \\
\hline & Cloeodes & 0 & 0 & 0 & 9 & 0 & 0 \\
\hline & Cryptonympha & 0 & 0 & 2 & 3 & 0 & 4 \\
\hline & Baetidae type 3 & 0 & 0 & 0 & 0 & 1 & 0 \\
\hline & Baetidae type 4 & 0 & 0 & 0 & 0 & 2 & 0 \\
\hline & Paracloeodes & 0 & 0 & 0 & 0 & 0 & 7 \\
\hline & Tupiara & 0 & 0 & 0 & 6 & 0 & 0 \\
\hline & Waltzoyphius & 0 & 6 & 6 & 9 & 0 & 11 \\
\hline & Zelusia & 0 & 0 & 0 & 2 & 1 & 0 \\
\hline \multicolumn{8}{|l|}{ Leptophlebiidae } \\
\hline & Farrodes & 3 & 4 & 3 & 51 & 5 & 23 \\
\hline & Hagenulopsis & 6 & 21 & 0 & 12 & 1 & 8 \\
\hline & Hermanella & 0 & 0 & 0 & 2 & 0 & 0 \\
\hline & Hylistes & 3 & 2 & 0 & 0 & 0 & 0 \\
\hline & Massartela & 0 & 0 & 0 & 0 & 0 & 1 \\
\hline & Miroculis & 1 & 0 & 0 & 1 & 0 & 3 \\
\hline & Thraulodes & 0 & 14 & 0 & 26 & 0 & 2 \\
\hline \multicolumn{8}{|l|}{ Leptohyphidae } \\
\hline & Leptohyphes & 19 & 28 & 9 & 11 & 1 & 3 \\
\hline & Traverhyphes & 10 & 0 & 0 & 0 & 16 & 1 \\
\hline & Tricorythopsis & 0 & 0 & 1 & 0 & 1 & 4 \\
\hline \multicolumn{8}{|l|}{ Ephemeridae } \\
\hline & Haxagenia & 0 & 0 & 0 & 0 & 0 & 1 \\
\hline \multicolumn{8}{|l|}{ Plecoptera } \\
\hline \multicolumn{8}{|l|}{ Perlidae } \\
\hline & Anacroneuria & 1 & 4 & 8 & 13 & 0 & 9 \\
\hline & Kempnyia & 0 & 0 & 2 & 5 & 0 & 0 \\
\hline & Macrogynoplax & 0 & 0 & 1 & 2 & 0 & 0 \\
\hline \multicolumn{8}{|l|}{ Gripopterygidae } \\
\hline & Paragripopteryx & 0 & 0 & 0 & 0 & 2 & 0 \\
\hline & Tupiperla & 0 & 0 & 0 & 0 & 2 & 0 \\
\hline
\end{tabular}


Appendix 3. Continued...

\begin{tabular}{|c|c|c|c|c|c|c|c|}
\hline Order/family & Genera & SF1 & SF2 & SF3 & SF4 & SF5 & SF6 \\
\hline \multicolumn{8}{|l|}{ Trichoptera } \\
\hline \multicolumn{8}{|l|}{ Hydropsychidae } \\
\hline & Leptonema & 2 & 8 & 4 & 2 & 1 & 4 \\
\hline & Macronema & 0 & 0 & 1 & 7 & 0 & 0 \\
\hline & Macrostemum & 0 & 0 & 1 & 1 & 0 & 0 \\
\hline & Smicridea & 9 & 25 & 6 & 14 & 2 & 3 \\
\hline \multicolumn{8}{|l|}{ Leptoceridae } \\
\hline & Atanatolica & 0 & 0 & 0 & 1 & 0 & 0 \\
\hline & Amphoropsyche & 0 & 0 & 0 & 0 & 0 & 1 \\
\hline & Nectopsyche & 0 & 0 & 0 & 1 & 0 & 2 \\
\hline & Oecetis & 0 & 0 & 0 & 0 & 0 & 4 \\
\hline \multicolumn{8}{|l|}{ Odontoceridae } \\
\hline & Marilia & 0 & 0 & 1 & 9 & 0 & 6 \\
\hline & Barypenthus & 0 & 0 & 0 & 20 & 0 & 0 \\
\hline \multicolumn{8}{|l|}{ Calamoceratidae } \\
\hline & Phylloicus & 0 & 0 & 5 & 4 & 0 & 0 \\
\hline \multicolumn{8}{|l|}{ Sericostomatidae } \\
\hline & Grumicha* & 1 & 2 & 0 & 2 & 0 & 5 \\
\hline \multicolumn{8}{|l|}{ Helicopsychidae } \\
\hline & Helicopsyche & 0 & 0 & 1 & 0 & 0 & 2 \\
\hline \multicolumn{8}{|l|}{ Hydrobiosidae } \\
\hline & Atopsyche & 0 & 0 & 0 & 4 & 0 & 0 \\
\hline \multicolumn{8}{|l|}{ Polycentropodidae } \\
\hline & Cyrnellus & 0 & 5 & 0 & 0 & 0 & 0 \\
\hline & Polyplectropus & 0 & 25 & 0 & 6 & 0 & 1 \\
\hline \multicolumn{8}{|l|}{ Glossosomatidae } \\
\hline & Mexitrichia & 0 & 0 & 0 & 0 & 0 & 1 \\
\hline \multicolumn{8}{|l|}{ Philopotamidae } \\
\hline & Chimarra & 0 & 1 & 0 & 0 & 0 & 1 \\
\hline \multicolumn{8}{|l|}{ Hydroptilidae } \\
\hline & Hydroptila & 2 & 0 & 0 & 0 & 0 & 0 \\
\hline Richness & & 13 & 15 & 18 & 31 & 15 & 27 \\
\hline Abundance & & 65 & 151 & 104 & 332 & 81 & 131 \\
\hline
\end{tabular}

